\title{
The impact of corporate identity on corporate social responsibility disclosure
}

\author{
Anne Michaels ${ }^{*}$ and Michael Grüning
}

\begin{abstract}
Corporate social responsibility (CSR) is of increasing importance for the long-term success of corporations. Extending existing literature this paper explores corporate identity as important determinant for CSR disclosure. The relationship was examined based on 498 German companies that provided English language CSR reports and responded to a company survey measuring CSR-oriented corporate identity. CSR disclosure has been analyzed with an automated content analysis technique using artificial intelligence. Results indicate that value chain and future-oriented dimensions, which were more pronounced in mature CSR concepts, foster CSR disclosure, while introversive corporate identity dimensions that were strong in low level CSR concepts hinder the release of CSR information. The paper shows that a tradition of social responsibility and values results into a low perceived need for legitimacy and outwards communication. The findings support the view that that a combination of voluntary disclosure theory and legitimacy theory is necessary to explain the drivers and constraints of CSR disclosure.
\end{abstract}

Keywords: CSR disclosure, Corporate identity, Content analysis, Survey, CSR determinants

\section{Introduction}

Within the last two decades, CSR disclosure by firms motivated an increasing number of research studies examining the motivation of this disclosure. Findings support that CSR disclosure is value relevant (Clarkson et al. 2013; Plumlee et al. 2015), increases earnings quality (Francis et al. 2008), analyst forecast accuracy (Dhaliwal et al. 2012) and firm level cost of capital (Michaels and Grüning 2017).

Firms also use CSR disclosure to differentiate from competitors and as a marketing tool (Porter and Kramer 2006). Empirical evidence suggests that the integration of CSR in corporate strategy might establish a competitive advantage (Carroll and Shabana 2010). Although firms may attempt to implement real CSR concepts, there is a tendency of "greenwashing" (Laufer 2014). In line with the missing causal link between CSR performance and CSR disclosure stakeholders mainly regard the latter as not trustworthy (Newell and Goldsmith 2001). Volkswagen's "Diesel Dupe" is a contemporary example. CSR disclosure credibility increases if aligned with corporate strategy (McWilliams and Siegel 2001). While

\footnotetext{
* Correspondence: anne.michaels@gmx.de

Department of Economic Sciences and Media, Institute of Business

Administration, Group Accounting and Managerial Control, IImenau

University of Technology, Helmholtzplatz 3, 98693 IImenau, Germany
}

quite some research examined internal determinants to support the strategic integration of CSR (e.g. Engert et al. 2016; Lozano 2013, 2015) only a few studies focussed on the internal aspects facilitating CSR disclosure. Prior research outlined a scheme to connect corporate identity and CSR (Otubanjo 2013). The "identity-revealing nature of CSR activities" is crucial in building a long-term sustainable corporate image (Du et al. 2010, p. 17) and a successful CSR strategy (Heikkurinen and Ketola 2012) but has been rarely addressed in the literature. Nevertheless, identity-based values and attributes as well as their communication are considered key factors for entrepreneurial success (He and Balmer 2007). Therefore, this paper examines if the degree of CSR-orientation in corporate identity is an important managerial driver of CSR disclosure. Results show that corporate identity significantly influences CSR disclosure even though they reveal an ambiguous pattern. Whereas the corporate identity dimensions "strategic integration" and "CSR application" facilitate, "employee integration" and "attitude awareness" inhibit CSR disclosure. CSR disclosure is objectively measured using an artificial intelligence based narrative analysis of CSR reports from 2013/14. CSRoriented corporate identity is extracted from a company survey. Whereas the total sample consists of 498 
companies, the intersecting sample (providing data for all main variables) consists of 108 German companies. The paper contributes to existing literature by revealing insights on so far unobserved determinants of CSR disclosure. It supports that managerial activities can shape internal drivers of CSR disclosure to obtain related financial benefits. Moreover, the paper provides quantitative data to the state of the art of corporate identity profiles and CSR disclosure of German firms.

The paper is structured as follows. The next section reviews the existing literature and develops the hypotheses. In the third section research design, sample selection and variable measurement are described. Section four provides the results. The final section concludes.

\section{Related research and hypothesis development CSR disclosure}

Numerous theoretical frameworks have been used to understand CSR as a relevant real world phenomenon. Clarkson et al. (2008) categorizes CSR accounting research into three broad fields of interest; (i) value relevance of CSR disclosure; (ii) determinants and constraints regarding the disclosure of CSR information; and (iii) the relationship between CSR performance and CSR disclosure. Whereas this study relates to the second group, findings from the third support the hypotheses development.

As a particular type of voluntary non-financial disclosure, CSR disclosure is believed to reduce information asymmetry between managers and investors (Dhaliwal et al. 2011). Voluntary disclosure theory suggests that voluntary disclosure is used by well performing companies to differentiate from low performers in order to avoid an adverse selection problem (Verrecchia 1983). High CSR performers disclose more CSR information as they expect to benefit on financial markets (Reverte 2012). In contrast, low performers disclose less in order to prevent negative effects due to capital market participants expecting a financial risk (Dhaliwal et al. 2011).

Nevertheless, prior studies revealed that CSR disclosure in particular is somewhat different from other types of non-financial information (Guidry and Patten 2012). There was much evidence of a severe mismatch between claims made in CSR disclosure and the implementation of CSR programs (Baumann-Pauly et al. 2013). Therefore legitimacy theory contrastingly argues that CSR low performers disclose more CSR information to legitimate themselves (Cho et al. 2012, p. 21). In this view, public pressure from the social and political environment is regarded as the main determinant of CSR disclosure (Cho and Patten 2007). While empirical findings support political cost (Reverte 2012) and increasing stakeholder pressure (Young and Marais 2012) to affect CSR disclosure, evidence of a causal connection between CSR performance and CSR disclosure is mixed (Plumlee et al. 2015). Only a few studies empirically explore this relationship with a limited focus on ecological disclosure (Cho et al. 2012). As a result, some research assumes a complementary relationship between both theoretical concepts; whereas voluntary disclosure theory explains the volume of CSR disclosure, legitimacy theory elucidates patterns in the disclosure (Clarkson et al. 2008).

As a consequence, prior research explores the individual determinants of CSR disclosure in greater details (Hahn and Kühnen 2013) and distinguished internal and external factors (Fifka 2013). The economic system, national culture, stakeholder orientation and company visibility, etc. are regarded as external factors. Companies in state-led market economies are found to report in a more aggregated way about CSR policies and provide more information on business behavior, labor concerns and environmental issues than companies in liberal market economies (Young and Marais 2012). In the context of national culture, companies in countries with a pronounced long-term orientation are considered to disclose more CSR information (Once and Almagtome 2014). Stakeholder orientation also positively influences CSR disclosure (Van der Laan Smith et al. 2005). Finally, company visibility is found to be an important driver of CSR disclosure (Gamerschlag et al. 2010). Industry affiliation, firm size, financial performance and capital market orientation are regarded internal determinants of CSR disclosure. Previous studies show that companies in CSR-sensitive industries like chemicals, mining or energy disclose more CSR information (Shnayder et al. 2016; Young and Marais 2012). In addition, CSR disclosure is considered to improve with increasing firm size (Wickert et al. 2016), financial performance (Haniffa and Cooke 2005) and capital market orientation (Heitzman et al. 2010).

\section{The relevance of corporate identity for CSR disclosure}

Further, more abstract internal CSR disclosure determinants received little attention so far but might help to understand how voluntary disclosure theory and legitimacy theory explain CSR disclosure. Du et al. (2010, p. 11) argue that a perceived "CSR fit" is an important internal factor driving the credibility of CSR disclosure. This fit relates to a perceived match between disclosed CSR information and corporate identity (Hristache et al. 2013). Corporate identity is derived from shared values and beliefs (Van Riel and Fombrun 2007) and comprises what is central, enduring and distinctive about the company (Albert and Whetten 1985). Corporate identity attributes can be detected by observing a company's strategy, behavior, rules, and structure (Melewar and Karaosmanoglu 2006). Desirable characteristics of corporate identity are a high quality mentality, supreme products, financial 
stability, an excellent working environment, as well as a sensitivity for CSR aspects (Einwiller and Will 2002).

$\mathrm{He}$ and Balmer (2013) connect an effective corporate identity management with an improved corporate image in the short term and a better corporate reputation in the long term. Corporate image relates to the perception of expressed corporate identity (Margulies 1977). Not the information content of a message but what receivers perceive is relevant for establishing an corporate image (Boulding 1956). Balmer \& Greyser (2006, p. 735) refer to corporate image as "various outbound communications channels deployed by organizations to communicate with customers and other constituencies". This view allows managerial activities to significantly affect both, corporate identity and image (Gioia et al. 2000). Corporate image is regarded as a direct consequence of corporate identity that the firm can control comprehensively (Balmer and Greyser 2003). Accordingly, CSR disclosure is regarded a major determinant of corporate image. Hopwood (2009, p. 437) suggest that companies defend with CSR disclosure by "providing a new face to the outside world while protecting the inner workings of the organization from external view". Simultaneously, public scandals uncover unethical corporate activities (Brennan et al. 2013). Consistently, Michaels and Grüning (2016a) find that increased CSR disclosure has a positive impact corporate reputation.

Altogether, prior research revealed an interdependency between corporate identity and corporate strategy ( $\mathrm{He}$ and Balmer 2013). In this context, Otubanjo (2013) as well as Venturelli et al. (2017) acknowledge the importance of this connection for CSR concepts. Heikkurinen \& Ketola (2012, p. 332ff) suggest an "awareness approach" for the integration of CSR into corporate strategy. Here, CSR is part of the firm's ethical, political and intrinsic convictions and a lack of credibility may never exist. Choosing CSR initiatives that address the entire organization as well as all dimensions of CSR is crucial in this context (Lozano 2012). Various views exist on the relationship between CSR performance and CSR disclosure. The adoption of CSR practices and values may lead to differentiating characteristics in the market (Porter and Kramer 2006). Following this business case approach companies align their CSR activities to create a competitive advantage that may increase profits or create additionally value added (Michaels and Grüning 2016b). Alternatively, the resource-based view of CSR suggests that companies engage in CSR in order to create positive internal and external benefits that enable a "more efficient use of resources" (Branco and Rodrigues 2006, p. 120). Both view call for an internal strategic adoption of CSR principles. Critics argue that these purely economic approaches endanger the moral foundations of CSR and inhibit its proper implementation (Nijhof and Jeurissen 2010).
Baumgarth and Binckebanck (2011) note that the establishment of a CSR-oriented corporate identity and culture are preconditions to achieve a reliable and trustworthy image and reputation. Both are highly affected by CSR disclosure (Guidry and Patten 2012). Consequently, the integration of CSR into the corporate identity is crucial for a successful CSR concept (McShane and Cunningham 2011). Managers utilize corporate identity to give organizational members "some sense of purpose" that motivates them to achieve common goals (Cornelissen 2002, p. 266). Corporate identity management enables the ability to express individuality, to manifest differentiating attributes, to set and express strategy as well as to communicate effectively (Balmer 2001). In most cases the alignment of corporate identity towards CSR requires the adoption of new values and beliefs as well as the definition of a new strategy and vision (Heikkurinen and Ketola 2012). Furthermore, the adoption of CSR principles requires most companies to revise or establish processes and structures (Hristache et al. 2013). Accordingly, Lozano et al. (2016) found a strong reciprocal relationship for organisational change management and CSR disclosure.

Credibility is an important issue for CSR disclosure (Lock and Seele 2016). Inconsistencies between the current status of CSR implementation and its communication have severe destructive consequences (BaumannPauly et al. 2013, p. 701). Hence, if companies face difficulties in creating credibility for their CSR programs, those companies that dispose over high conformance would use it to create credibility through increased CSR disclosure. Accordingly, CSR-oriented corporate identity is an important internal determinant of CSR disclosure and the following hypothesis is formulated:

\section{H1: A high level of CSR-oriented corporate identity is positively associated with the level of CSR disclosure.}

\section{Sample, variable definition, and methodology Sample selection}

The analysis is based on 498 listed and non-listed German companies. Due to the history of an advanced social welfare system German companies likely assume a distinctive social responsibility (Chen and Bouvain 2009). Germany is also known to have an extraordinarily high number of "hidden champions" (Simon 2012). These companies are often family-owned and characterized by a high social responsibility (Spiegel and Block 2013, p. 12). Capital market sustainability ratings support the view that German companies have an outstanding sustainability performance, beating comparable US, France and Austria firms (Sustainalytics 2012).

In line with other empirical CSR studies (e.g. Fatma et al. 2016; Huang et al. 2014; Liu et al. 2014) a 
convenience sampling has been applied (Table 1). Companies are selected based on (i) two German image and sustainability rankings (172); (ii) a list of the German ministry of environment containing firms that publish CSR reports (266); and (iii) randomly chosen companies of the prime and general standard of the Frankfurt Stock Exchange (60). Altogether, 327 of the 498 firms (66.6\%) English language CSR reports (standalone CSR reports, integrated corporate reports or website information) could be collected from corporate websites or the GRI reporting database for reporting year 2013/2014. The latent construct of CSR-oriented corporate identity is measured using a company survey. $226(45.4 \%)$ of the 498 sample companies replied of which 149 (29.9\%) firms provide usable answers. In total, the intersecting sample of firms for which we could obtain CSR disclosure as well as usable answers from the company survey consists of 108 companies.

\section{AIMD}

The dependent CSR disclosure variable is measured using automated content analysis deviated from Artificial Intelligence Measurement of Disclosure (AIMD) (Grüning 2011). AIMD measures the extent to which text documents refer to specified topics. Different to ordinary word count approaches, AIMD is able to partly consider the context of information, including thesaurus and syntax (Grüning 2011). In a first step (training phase) a coding scheme must be developed to identify certain topics in text documents. In a second step (application phase) the topics of large quantities of texts can be classified using this coding scheme. Figure 1 summarizes the basic procedure. The coding scheme consists of semantic units (N-grams) that are "connotative categorical equivalents" for a specified type of information (Grüning 2011, p. 510), i.e. refer to the same topic. Using various dictionaries $\mathrm{N}$-grams are automatically standardized and the resulting AIMD coding scheme is almost not affected by grammar and orthography of the underlying texts.

Although the coding scheme can be generated manually, in this paper a fully automated approach is used because of superior objectivity. In line with linguistic practice (Archer 2009, p. 2) N-grams appearing frequently in the CSR reports and not frequently in the annual reports (excluding CSR related chapters that are removed manually) are regarded as typical for CSR reporting. More specifically, for 29 firms from the German DAX and MDAX CSR annual reports (except of CSR chapters) for 2014 are enumerated into $\mathrm{N}$-grams of up to three consecutive words (excluding stopwords). All $\mathrm{N}$-grams that occur in $\mathrm{x}$ annual reports (except of CSR chapters) and y CSR reports are collected separately. Lists with $y>x$ are potentially indicative for CSR reporting. An AIMD content analysis is performed using each of the $841=29 \cdot 29 \mathrm{~N}$-gram lists. The one that best replicates the CSR content analysis of Gamerschlag et al. (2010) is finally chosen. The N-gram list that includes all

Table 1 Sample Distribution

\begin{tabular}{|c|c|c|c|c|}
\hline 1 & 2 & 3 & 4 & \\
\hline $\begin{array}{l}\text { No. of in \% } \\
\text { companies }\end{array}$ & $\begin{array}{l}\text { No. of CSR in \% } \\
\text { reports }\end{array}$ & $\begin{array}{l}\text { No. of CSR in \% } \\
\text { surveys }\end{array}$ & $\begin{array}{l}\text { No. of companies } \\
\text { with report + survey }\end{array}$ & in $\%$ \\
\hline Initial sample & & & Full sample & \\
\hline
\end{tabular}

Panel A: Distribution by Industry

Industry

Banks and Insurance 30

Chemicals, rubber, plastics, non-metallic products 60

Food, beverages, tobacco

\section{0}

Gas, water, electricity, construction

Machinery, equipment, furniture, recycling

Other services

Post, telecommunications, transport, publishing

Wholesale \& retail trade

Total

$\begin{array}{ll}6.02 & 18 \\ 12.05 & 50 \\ 10.44 & 35 \\ 6.02 & 19 \\ 21.08 & 88 \\ 21.49 & 51 \\ 7.43 & 26 \\ 15.46 & 40 \\ 100.00 & 327\end{array}$

Panel B: Distribution by Stock market activity

Stock market activity

Listed

Not listed

$\begin{array}{ll}5.50 & 14 \\ 15.29 & 16 \\ 10.70 & 11 \\ 5.81 & 10 \\ 26.91 & 26 \\ 15.60 & 38 \\ 7.95 & 12 \\ 12.23 & 22 \\ 100.00 & 149\end{array}$

$9.40 \quad 9$
498

\begin{tabular}{lll}
30.87 & 41 & 37.96 \\
69.13 & 67 & 62.04 \\
100.00 & 108 & 100.00 \\
\hline
\end{tabular}



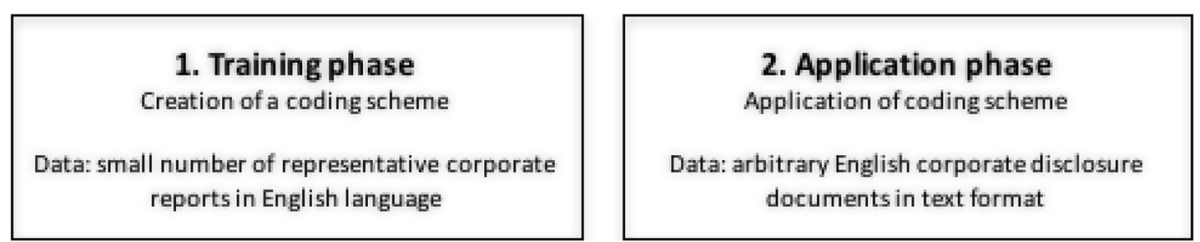

Fig. 1 Basic idea of AIMD disclosure level measurement. Figure 1 shows the two basic steps of AIMD disclosure measurement. The first step consists of the training phase where a coding scheme is created based on a small number representative corporate reports in English. The second step consists of the application phase of the coding scheme on arbitrary English corporate disclosure documents in text form

$\mathrm{N}$-grams appearing in 15 of the 29 CSR reports but in only seven of the annual reports (except of CSR chapters) establishes the final coding scheme (see Table 2). While for many of the $\mathrm{N}$-grams the relation to CSR is straight, some likely remain as artefacts because the coding scheme has been established empirically. Those are not removed manually to preserve objectivity of the content analysis. Altogether, the correlation coefficient of the AIMD results and the frequency counts of Gamerschlag et al. (2010) is $0.76(p=0.00)$.

To obtain the CSR disclosure measure for the sample reports AIMD frequencies are determined using this coding scheme in the application phase. A higher AIMD frequency represents a higher level of CSR disclosure. ${ }^{1}$

\section{Company survey}

In order to characterize CSR-oriented corporate identity comprehensively, eight dimensions of interest are derived from prior literature on CSR and surveys measuring general corporate identity (Sackmann 2006): (i) People orientation (McShane and Cunningham 2011); (ii) Leadership (Strand 2014); (iii) Innovation (Fischer and Sawczyn 2013); (iv) Work related issues (Collier and Esteban 2007); (v) Stakeholder orientation (Brennan et al. 2013); (vi) Communication (Du et al. 2010); (vii) value orientation (Bondy et al. 2012); and (viii) Strategy/ vision (Heikkurinen and Ketola 2012). For each dimension relevant items are generated in the survey. Following Martins (2007), the survey is structured in a threepillar-order (see Table 3) where the items of one dimension are not in a subsequent order. The advantage of this three-fold approach is that all identity levels (artifacts, values and underlying assumptions) are captured. Whereas artifacts are predominantly included in the beginning section, values, beliefs and underlying assumptions are mainly recorded within the other two parts. Think-aloud-protocols (Ericsson 2006) and verbal probing (Willis 2006) are applied to ensure the validity of the questionnaire. The questionnaire was sent out in spring 2015 with reminders after about 2 months. Data collection finished after approximately 4 months. Construct validity of the company survey are evaluated using exploratory factor analysis. An average Cronbach's alpha of 0.96 demonstrates the reliability of the survey items. The average Kaiser-Meyer-Olkin criterion is 0.91 and indicates a "marvelous" sampling adequacy. Based on a screw test, exploratory factor analysis establishes four major factors that comprise CSR-oriented corporate identity which are (i) strategic integration; (ii) CSR application; (iii) employee integration; and (iv) attitude awareness. All factors have an Eigenvalue above 1. Strategic integration refers to the relevance of CSR in a company's strategic planning process and its market positioning. CSR application is related to CSR activities and artefacts. The dimension employee integration reflects the relevance in assuming social responsibility. Attitude awareness indicates the degree of corporate awareness about CSR-related values and principles. The retrieved factors are consistent with related literature (e.g. He and Balmer 2007; Melewar and Karaosmanoglu 2006). Statistical model fit indicators are in line with standard recommendations (Unterreitmeier 2004). The four factors are used as independent variables in the regression model.

\section{Empirical model}

To test H1, the relationship between CSR-oriented corporate identity and CSR disclosure is examined. The following multivariate regression analysis model that controls for various other determinants of CSR disclosure is applied:

$$
\begin{aligned}
\text { DISCLOSURE }= & \beta_{0}+\beta_{1} \text { STRATEGY } \\
& +\beta_{2} \text { APPLICATION } \\
& +\beta_{3} \text { EMPLOYEE } \\
& +\beta_{4} \text { AWARENESS } \\
& +\beta_{5} \operatorname{logSIZE}+\beta_{6} \text { INDUSTRY } \\
& +\beta_{7} \log \text { INOF } \\
& +\beta_{8} \text { INCORPORATION } \\
& +\beta_{9} \text { LISTED } \\
& +\beta_{10} \text { STANDALONE } \\
& +\beta_{11} \text { GRI }+\varepsilon
\end{aligned}
$$

The dependent variable DISCLOSURE is an AIMD $\mathrm{N}$-gram-count based disclosure score. The main independent variables are the four factor variables that 
Table 2 Coding scheme (121 codes)

\begin{tabular}{|c|c|c|}
\hline academic & education training & ilo organization \\
\hline academy & emission energy & $\begin{array}{l}\text { important } \\
\text { stakeholder }\end{array}$ \\
\hline analysis materiality & emission reduction & $\begin{array}{l}\text { information } \\
\text { sustainability }\end{array}$ \\
\hline animal & emission scope & initiative support \\
\hline apprentice & employee germany & intercultural \\
\hline association freedom & employee health & international labor \\
\hline assurance report & employee make & $\begin{array}{l}\text { international labor } \\
\text { organization }\end{array}$ \\
\hline balance life & employee need & issue sustainability \\
\hline balance life work & employee new & labor organization \\
\hline bargain & employee opportunity & labor standard \\
\hline bargain collective & energy include & lighting \\
\hline biodiversity & energy resource & man woman \\
\hline business travel & energy saving & $\begin{array}{l}\text { management } \\
\text { safety }\end{array}$ \\
\hline carbon disclosure & energy water & $\begin{array}{l}\text { management } \\
\text { sustainability }\end{array}$ \\
\hline carbon footprint & $\begin{array}{l}\text { engagement } \\
\text { stakeholder }\end{array}$ & $\begin{array}{l}\text { management } \\
\text { waste }\end{array}$ \\
\hline carbon reduce & environment impact & mentor \\
\hline $\begin{array}{l}\text { chain management } \\
\text { supply }\end{array}$ & environmental issue & ngos \\
\hline charitable & $\begin{array}{l}\text { environmental } \\
\text { performance }\end{array}$ & occupational safety \\
\hline child labor & environmental reduce & offer program \\
\hline combustion & $\begin{array}{l}\text { environmental } \\
\text { responsibility }\end{array}$ & organization s \\
\hline community local & $\begin{array}{l}\text { environmental } \\
\text { social standard }\end{array}$ & pollution \\
\hline $\begin{array}{l}\text { compact global } \\
\text { principle }\end{array}$ & equal opportunity & $\begin{array}{l}\text { process } \\
\text { procurement }\end{array}$ \\
\hline condition working & $\begin{array}{l}\text { gas greenhouse } \\
\text { reduce }\end{array}$ & $\begin{array}{l}\text { product } \\
\text { responsibility }\end{array}$ \\
\hline $\begin{array}{l}\text { consumption } \\
\text { electricity }\end{array}$ & ghg & program support \\
\hline $\begin{array}{l}\text { consumption energy } \\
\text { reduce }\end{array}$ & global principle & project social \\
\hline consumption resource & governmental non & project support \\
\hline consumption water & $\begin{array}{l}\text { governmental } \\
\text { non organization }\end{array}$ & rate turnover \\
\hline convention & $\begin{array}{l}\text { governmental } \\
\text { organization }\end{array}$ & recycle \\
\hline country employee & greenhouse reduce & recycling \\
\hline course training & grus initiative & reduce use \\
\hline $\begin{array}{l}\text { development } \\
\text { professional }\end{array}$ & $\begin{array}{l}\text { grus initiative } \\
\text { reporting }\end{array}$ & relate work \\
\hline dialog stakeholder & hazardous & renewable use \\
\hline discrimination & hazardous waste & $\begin{array}{l}\text { report } \\
\text { sustainability }\end{array}$ \\
\hline
\end{tabular}

Table 2 Coding scheme (121 codes) (Continued)

\begin{tabular}{lll}
\hline disposal waste & help program & reuse \\
donate & hiring & social standard \\
drinking & hour work & sponsorship \\
drinking water & hour working & square \\
eco & illness & strategy \\
& & sustainability \\
economic environmental & ilo & use water \\
economic environmental & ilo labor organization & volunteer \\
social & & \\
& & waste water \\
\hline Words as parts of $\mathrm{N}$-grams are order alphabetically and stemmed to their root
\end{tabular}

constitute CSR-oriented corporate identity. The variable strategic integration, STRATEGY, comprises many future-oriented survey items concerning mission, vision and targets as well as the role of CSR for strategic positioning. The variable CSR application, APPLICATION, joins all items related to CSR activities. As a third factor, the variable employee integration, EMPLOYEE, captures items covering how good CSR is implemented as a participative organizational concept. The last variable approach awareness, AWARENESS, covers how important CSR-related values are for a company.

Following prior empirical work, the model controls for the effects of structural company characteristics that impact the level of CSR disclosure (Fifka 2013). Data is retrieved from the Orbis database. Prior empirical findings documented that firm size is significantly related to CSR disclosure because larger companies are exposed to increased external stakeholder pressures (Guidry and Patten 2012) or larger companies benefit from an economy of scale regarding organizational cost for CSR (Baumann-Pauly et al. 2013). In this paper, logSIZE is alternatively proxied as the natural logarithm of the number of employees or the logarithm of annual sales. Because of structurally identical results only the results of the former are tabulated and results of the robustness analysis using the latter are not reported.

Prior research suggests industry affiliation, INDUS$T R Y$, is an important control variable because companies in particular industries are exposed to higher public pressure (Jackson and Apostolakou 2010) and regulation

Table 3 Questionnaire Structure

\begin{tabular}{ll}
\hline Section & Explanation \\
\hline $\begin{array}{c}\text { - Types and } \\
\text { organization } \\
\text { of CSR }\end{array}$ & $\begin{array}{l}\text { Section } 1 \text { aims to capture the existing forms of CSR in } \\
\text { the company and their organization and anchoring in } \\
\text { directives. }\end{array}$ \\
$\begin{array}{cl}\text { - Application } \\
\text { of CSR }\end{array}$ & $\begin{array}{l}\text { Section } 2 \text { is intended to cover how the company uses } \\
\text { CSR, what objectives it pursues. }\end{array}$ \\
$\begin{array}{c}\text { - Cultural } \\
\text { anchor }\end{array}$ & Section 3 is to identify the values and levels at which \\
\hline
\end{tabular}


of CSR issues, such as environmental protection, may vary between industries (Fischer and Sawczyn 2013).

Profitability is included as a control variable although the relationship between CSR disclosure and profitability is inconclusive (McWilliams et al. 2006). However, the resource based view suggests that financially high performing companies dedicate more resources to CSR activities and therefore increase their CSR disclosure (Russo and Fouts 1997). The natural logarithm of sales per employee $(\log P R O F)$ proxies for the economic potential of profitability because of data availability considerations. Robustness test (not reported) indicate structural identical results for other proxies (natural logarithm of earnings before tax; of return on assets; of return on sales) that are constrained by data availability.

In addition, controls for the effect of disclosure regulation with the variables legal form and stock market activity are implemented. Prior research revealed the interaction of mandatory and voluntary disclosure to affect the disclosure level (Dye 1990). Hence, companies which are subject to larger mandatory disclosure release more voluntary information. Therefore, the indicator STOCKCOMPANY is included to control for this effect. Similarly, the indicator LISTED controls for stock market activities as listed companies are regarded to have higher voluntary CSR disclosure levels (Adhikari and Tondkar 1992) because of their multi-investor ownership structure (Rouf 2011).

Furthermore, it we control for the effects of different $C S R$ reporting types. These types, such as standalone reports, integrated reporting or website information may vary in volume, structure and content (Dhaliwal et al. 2011). Cho et al. (2015) found that firms with standalone CSR reports significantly disclose more CSR information. Therefore, STANDALONE is included as an additional control. Moreover, the model controls for the effects of the application of reporting guidelines of the GRI. Empirical findings support that the adoption of international reporting standards such as GRI leads to increased harmonization and transparency in crosscountry comparisons as well as to higher levels of CSR disclosure (Fortanier et al. 2011; Nikolaeva and Bicho 2011). Accordingly, the indicator GRI is included in the analysis. Table 4 offers a summary of all variables, abbreviations and data sources.

\section{Results and discussion Descriptive statistics}

Table 5 summarizes descriptive statistics for all continuous variables included in Eq. (1). All nominal and dichotomous variables are omitted. Variables STRATEGY, APPLICATION, EMPLOYEE, AWARENESS are factor values comprising CSR-oriented corporate identity. They result from the exploratory factor analysis of survey items described in "Company survey" section. The item variables are standardized before exploratory factor analysis. Therefore, the factor values have a mean close to 0 and a SD close to 1 .

Table 6 shows the Pearson correlation of CSR disclosure (DISCLOSURE), all independent variables and the control variables without industry affiliation (INDUSTRY). The correlation coefficients between the independent variables do not indicate the presence of multicollinearity as the highest value is 0.655 (Farrar and Glauber 1967). In line, the variance inflation factors (mean of 1.57) also do not reveal multicollinearity.

Consistent with the hypothesis, at least two independent variables, STRATEGY and APPLICATION, show a

Table 4 Data sources

\begin{tabular}{llll}
\hline Variable & Measure & & Source \\
\cline { 2 - 3 } & Abbreviation & Explanation & From company websites \\
\hline CSR disclosure & DISCLOSURE & CSR disclosure score measured by AIMD & Company survey \\
CSR application & STRATEGY & Degree of strategic integration of CSR & Company survey \\
Employee integration & APPLICATION & Degree of CSR application & Company survey \\
Approach awareness & EMPLOYEE & Degree of employeee integration & Company survey \\
Company size & AWARENESS & Degree of approach awareness & Orbis database \\
Industry affiliation & IOgSIZE & Logarithm of number of employees & Orbis database \\
Profitability & INDUSTRY & Industry classification & Orbis database \\
Legal form & IOgPROF & Logarithm of sales per employee & Orbis database \\
Stock market activity & INCORPORATION & Indicator for limited company on shares & Orbis database \\
Reporting type & LISTED & Indicator for listed companies & Own assessment \\
Application of GRI guidelines & STANDALONE & Indicator for standalone reporting & Company survey \\
\hline
\end{tabular}


Table 5 Descriptive Statistics

\begin{tabular}{llllll}
\hline Variable & Number & Mean & Std. Dev. & Min & Max \\
\hline DISCLOSURE & 327 & 314.09 & 402.23 & 0.00 & 2905.00 \\
STRATEGY & 149 & 0.01 & 0.95 & -2.96 & 1.90 \\
APPLICATION & 149 & 0.01 & 0.95 & -3.17 & 2.31 \\
EMPLOYEE & 149 & -0.01 & 0.97 & -3.28 & 1.82 \\
AWARENESS & 149 & 0.00 & 0.95 & -4.40 & 1.37 \\
logSIZE & 481 & 7.72 & 2.38 & 0.00 & 13.29 \\
logPROF & 459 & 5.81 & 1.34 & -1.47 & 14.29 \\
\hline
\end{tabular}

Only continuous variables included in Eq. (1) are shown. All nominal and dichotomous variables are omitted

Variables STRATEGY, APPLICATION, EMPLOYEE and AWARENESS are factor values comprising CSR-oriented corporate identity

They result from an exploratory factor analysis (EFA) of survey items relevant for the measurement of CSR-oriented corporate identity

The item variables have been standardized before EFA. Therefore, the factor values have a mean near to 0 and a SD close to 1

See Table 4 for variable explanations

significant positive correlation. The variables EMPLOYEE and AWARENESS indicate a weak negative correlation. Furthermore, a significant positive relationship between $\log P R O F$ and DISCLOSURE as well as between GRI and DISCLOSURE and STANDALONE and DISCLOSURE is found according to the expectations. However, the results do not reveal a strong positive relationship between company size and CSR disclosure which was reported by other researchers (BaumannPauly et al. 2013). Stand-alone reports correlate significantly positive with CSR disclosure.

Additionally, there is a significant negative correlation between INCORPORATION and LISTED and strategic integration. Furthermore, profitability is significantly negatively correlated with CSR application. These findings contradict with earlier empirical findings suggesting that higher public pressures generate superior CSR performance (Fischer and Sawczyn 2013).

\section{Regression results}

The hypothesis predicts a positive relationship between CSR-oriented corporate identity and CSR disclosure. Standardized regression coefficients (beta) and significance levels (p) for Equation (6) are reported in Table 7. The robustness of the models is ensured by subsequently adding the control variables (Models 1-8) for the same sample $(N=108)$. The explained variance $\left(\mathrm{R}^{2}\right)$ increases from $10.4 \%$ in Model 1 to $43.1 \%$ in Model 8 . The coefficient estimates of the control variables are generally consistent with the correlation analysis in Table 6. The issuance of standalone CSR reports (beta STANDALONE $=+$ $\left.0.327^{* * *}\right)$ and the application of GRI reporting guidelines (beta $\left._{G R I}=+0.331^{* * * *}\right)$ in particular indicate a highly significant positive association. Firm size (logSIZE) and profitability $(\log P R O F)$ had significant positive effects in Models 4-6. However, the final model (Model 8) does not show a significant relationship. There are no significant effects on CSR disclosure for stock companies (STOCKCOMPANY) or for companies that are listed on the Frankfurt Stock Exchange (LISTED). This results are contradictory to prior empirical findings for corporate disclosure in general (Healy and Palepu 2001). Different to prior research (Gamerschlag et al. 2010), a Wald test for joint significance of the control variable INDUSTRY (not tabulated) reveal no significant effect.

In line with the prediction, a significant positive impact of strategic integration (beta STRATEGY $=+0.165^{* *}$ ) and CSR application (beta APPLICATION $=+0.167^{* *}$ ) on CSR disclosure is found. Inconsistently with the hypothesis, employee integration (beta EMPLOYEE $=-0.167^{* * * *}$ ) and attitude awareness (beta AWARENESS $=-0.153^{*}$ ) are significantly negatively associated with CSR disclosure. These results are considered robust as estimates for STRATEGY, APPLICATION, EMPLOYEE, AWARENESS do not structurally differ between models. Notably, in

Table 6 Pearson Correlations

\begin{tabular}{|c|c|c|c|c|c|c|c|c|c|c|c|c|}
\hline & & (1) & (2) & (3) & (4) & (5) & (6) & (7) & (8) & (9) & (10) & (11) \\
\hline DISCLOSURE & (1) & 1 & & & & & & & & & & \\
\hline STRATEGY & (2) & $.193^{*}$ & 1 & & & & & & & & & \\
\hline APPLICATION & (3) & $.180^{*}$ & .038 & 1 & & & & & & & & \\
\hline EMPLOYEE & (4) & -.118 & .035 & .012 & 1 & & & & & & & \\
\hline AWARENESS & (5) & -.111 & .052 & .028 & .007 & 1 & & & & & & \\
\hline $\log S I Z E$ & (6) & .059 & -.081 & .008 & .119 & -.030 & 1 & & & & & \\
\hline logPROF & (7) & $.179^{*}$ & -.037 & $-.240^{*}$ & -.079 & -.048 & $-.354^{*}$ & 1 & & & & \\
\hline INCORPORATION & (8) & .004 & $-.218^{*}$ & -.081 & .067 & $-.143^{*}$ & $.360^{*}$ & -.070 & 1 & & & \\
\hline LISTED & (9) & .017 & $-.175^{*}$ & -.099 & -.024 & -.021 & $.323^{*}$ & -.069 & $.661^{*}$ & 1 & & \\
\hline STANDALONE & (10) & $.367^{*}$ & .073 & .126 & .026 & .132 & -.014 & .018 & $-.110^{*}$ & $-.114^{*}$ & 1 & \\
\hline GRI & (11) & $.440^{*}$ & $.265^{*}$ & .057 & .05 & .133 & .126 & .118 & .030 & .048 & $.227^{*}$ & 1 \\
\hline
\end{tabular}

A correlation coefficient with asterisk indicated that the correlation is statistically significant at the $10 \%$ level See Table 4 for variable explanations 
Table 7 Regression Results

\begin{tabular}{|c|c|c|c|c|c|c|c|c|}
\hline $\begin{array}{l}\text { Dependent } \\
\text { Variable = DISCLOSURE }\end{array}$ & $\begin{array}{l}\text { Model } 1 \\
\text { beta }\end{array}$ & $\begin{array}{l}\text { Model } 2 \\
\text { beta }\end{array}$ & $\begin{array}{l}\text { Model } 3 \\
\text { beta }\end{array}$ & $\begin{array}{l}\text { Model } 4 \\
\text { beta }\end{array}$ & $\begin{array}{l}\text { Model } 5 \\
\text { beta }\end{array}$ & $\begin{array}{l}\text { Model } 6 \\
\text { beta }\end{array}$ & $\begin{array}{l}\text { Model } 7 \\
\text { beta }\end{array}$ & $\begin{array}{l}\text { Model } 8 \\
\text { beta }\end{array}$ \\
\hline STRATEGY & $.220^{* * *}$ & $.215^{* * *}$ & $.257^{* * *}$ & $.261^{* * *}$ & $.283^{* * *}$ & $.281^{* * *}$ & $.256^{* * *}$ & $.165^{* *}$ \\
\hline APPLICATION & $.188^{* *}$ & $.182^{* *}$ & $.178^{* *}$ & $.224^{* *}$ & $.223^{* *}$ & $.225^{* *}$ & $.200^{* *}$ & $.167^{* *}$ \\
\hline EMPLOYEE & -.123 & -.13 & $-.152^{*}$ & -.134 & $-.143^{*}$ & $-.140^{*}$ & $-.166^{* *}$ & $-.167^{* * *}$ \\
\hline AWARENESS & -.116 & -.106 & -.110 & -.105 & -.090 & -.092 & -.114 & $-.153^{*}$ \\
\hline $\log S I Z E$ & & $.207^{*}$ & $.192^{*}$ & $.238^{*}$ & $.201^{*}$ & .194 & $.220^{* *}$ & .147 \\
\hline logPROF & & & & $.197^{*}$ & $.190^{*}$ & $.180^{*}$ & .118 & .063 \\
\hline INCORPORATION & & & & & .110 & .070 & .053 & .072 \\
\hline LISTED & & & & & & .061 & .107 & .082 \\
\hline STANDALONE & & & & & & & $.385^{* * *}$ & $.327^{* * *}$ \\
\hline GRI & & & & & & & & $.331^{* * *}$ \\
\hline INDUSTRY & No & No & Yes & Yes & Yes & Yes & Yes & Yes \\
\hline$R^{2}$ & $10 \%$ & $15 \%$ & $17 \%$ & $20 \%$ & $21 \%$ & $21 \%$ & $35 \%$ & $43 \%$ \\
\hline N & 108 & 108 & 108 & 108 & 108 & 108 & 108 & 108 \\
\hline
\end{tabular}

the final model (Model 8) all independent variables indicate roughly the same power of association. Therefore, the association of corporate identity and CSR disclosure is regarded to vary between the various aspects of corporate identity. In particular, those corporate identity dimensions which are more closely related to the value chain and future-oriented targets stimulate an increasing CSR disclosure compared to corporate identity dimensions with an introversive focus. Thus, the findings explicitly support neither voluntary disclosure theory nor legitimacy theory to explain the determinants of CSR disclosure. They rather indicate that CSR disclosure is different from other types of disclosure, as already proposed by Guidry and Patten (2012). In summary H1 is only confirmed partly.

To better understand the ambivalent effects of various corporate identity characteristics, four informal interviews with corporate CSR experts who participated in the survey have been conducted. ${ }^{2}$ The exploratory interviews provide some interesting thoughts about the results and could help in refining the hypotheses to stipulate further confirmative research. The findings from the interviews have not been used in evaluating the logical value of the hypotheses. The experts' feedback suggests that the diverging impacts of corporate identity dimensions might depend on the development stage of a CSR concept in companies. The level of corporate identity dimensions is expected to change according to the implementation status of CSR. Whereas attitude awareness and employee integration are more pronounced in an early phase of implementation, CSR application and strategic integration become more important with the maturity of the concept. In line with voluntary disclosure theory, CSR disclosure is expected to grow with the evolution of the concept. The results could indicate that the hard attributes of corporate identity, such as CSR artefacts and the relevance of CSR in the strategic planning process, promote CSR disclosure. This interpretation is corroborated by prior findings which suggest that strategic planning is also considered an important reason for CSR disclosure (Pérez and Rodríguez del Bosque 2011). According to the CSR experts, CSR disclosure has a target setting function and will only be provided once a CSR program becomes more precise. In line, the GRI considers CSR disclosure to be a milestone within the continuous improvement of CSR programs (Brown et al. 2009). The CSR experts also state that attitude awareness and employee integration have been relevant dimensions in their companies for a longer period of time than it has been common to adopt "fancy" CSR programs and disclose CSR information. As a consequence, these issues may remain stable over time and may not contribute to the variance of CSR disclosure content. Similarly, previous research reveals that companies with a longstanding social personality tend to invest less in CSR communication (Baumann-Pauly et al. 2013). As such, results may also suggest that less CSR disclosure does neither indicate if companies do not dispose over any CSR characteristics in their corporate identity nor to what extent these characteristics are existent. It can be 
suspected that companies with strong CSR values employ other means to create transparency and to appear trustworthy.

The regression results are regarded robust as the effects of the main variables remain stable over different models. Various other models that include a proxy for CSR performance are tested as well (not tabulated). Prior research uses CSR performance proxies from databases such as MSCI KLD or Bloomberg (Cho et al. 2013; Nelling and Webb 2008). For 41 firms environmental, social and governance performance indicators (total greenhouse gas emissions, employee turnover and board meeting attendance) could be obtained from Bloomberg. The results do not reveal a significant effect of CSR performance of CSR disclosure. Due to the low sample size, $\mathrm{CO}_{2}$ emissions reported in the CSR reports are used as alternative measure in line with prior literature (Clarkson et al. 2008, p. 308). The analysis based on a sample of 77 firms results (not tabulated) reveal again no significant effect of (this very narrow) CSR performance on CSR disclosure.

\section{Conclusion and future research}

Today, CSR information is a major component of companies' corporate disclosure. It is considered to mirror companies' CSR performance as a response to increasing stakeholder requirements and legitimate business operations. The growing interest in sustainability topics has also motivated many researchers to examine CSR disclosure. Prior research revealed a number of internal and external influential factors along with a number of benefits that companies gain from compiling and publishing CSR information.

The aim of this research study is to extend the knowledge of so far unobserved internal determinants of CSR disclosure. In summary, the results of this study suggest three major findings. First, characteristics of corporate identity are related to the development stage of a firm's CSR concept. Corporate identity dimensions that indicate a mature CSR concept are positively associated with companies' CSR disclosure. Firms that remain in an early phase of CSR development or that have a superficial CSR model disclose significantly less CSR information. This finding is in line with voluntary disclosure theory. Second, introversive corporate identity dimensions are more pronounced in a firm with low level CSR engagement. Value chain and future-oriented dimensions are more pronounced in a firm with high level CSR engagement. Third, the perceived need for legitimacy influences the degree of a firm's CSR disclosure. Companies that historically possess a corporate identity of strong attitude awareness and employee integration report less CSR information because they do not detect the need for legitimacy. Concerned companies consider aspects of these corporate identity dimensions to be ordinary business conduct. This finding is in line with legitimacy theory. It will be necessary to further investigate why these companies have this perception; they may use other means and channels to create a trustful relationship with their stakeholders.

In conclusion, the results of this study support the claim that a combination of voluntary disclosure theory and legitimacy theories (Clarkson et al. 2008) is necessary to explain the drivers and constraints of CSR disclosure as well as the relationship between CSR disclosure and CSR performance.

The empirical analysis contributes to CSR disclosure literature by examining further potential determinants and consequences of CSR disclosure, which have received little attention so far. To the authors' best knowledge, this study is the first that empirically examines the relationship between corporate identity and CSR disclosure. It extends the scope of research of what is known about firm's internal determinants of CSR disclosure. The discovery of corporate identity dimensions with ambiguous effects on CSR disclosure supports the growing field of researchers that state a complementary relationship between voluntary disclosure theory and legitimacy theory to explain CSR disclosure. Additionally, the findings underline the results from prior research (e.g. Dhaliwal et al. 2014) by demonstrating that the reporting framework has a substantial impact on the level of CSR disclosure: Companies that issue standalone CSR reports and apply the GRI guidelines achieve a significantly higher disclosure level. Other determinants like the legal form and stock market activity appear to be less important than expected.

From a methodological point of view, this is the first time that artificial intelligence is applied to the measurement of CSR disclosure. The study provides quantitative data on the state of the art of CSR disclosure of German firms. In addition, it develops a survey-based measurement tool to determine the degree of CSR orientation in firms' corporate identities and provides quantitative data on the current corporate identity profiles of German firms.

Limitations of the empirical work arose from potential conceptual and methodological shortcomings. With regard to the research question, it is possible that additional factors that have a direct, moderating or mediating impact on the theoretical constructs are not captured appropriately. Specifically, corporate identity is an abstract construct that is difficult to capture. Even though the corporate identity dimensions are based on an extensive literature review, they are potentially biased or incomplete. From a technical point of view, it is recognized that the cross-sectional design that was chosen because of research economic considerations severely limits results because of the probable but 
undeterminable time lag of corporate identity effects on CSR disclosure. Furthermore, the usual sampling issues of field research may limit the generalizability of results.

The findings of this study unveil a number of research paths that could be investigated in future research. Further research should examine the relationship between corporate identity and CSR disclosure on an international level or apply different measurement techniques to capture corporate identity. This may validate the findings and provide further insights into the interaction of CSR disclosure determinants derived from voluntary disclosure theory and legitimacy theory. Further research in this direction may also apply a mix of quantitative and qualitative approaches to obtain more in-depth knowledge about the interaction of CSR identity and CSR disclosure. The four exploratory interviews following the confirmatory hypotheses evaluation suggest some potential avenues for further research. Additional empirical research is also required to elaborate on the interaction between information asymmetry and trust in the context of CSR: do they have a cause-effect relationship or are they even substitutes for each other?

\section{Endnotes}

${ }^{1}$ For a detailed explanation of AIMD refer to Grüning (2011).

${ }^{2}$ The interviews were conducted by telephone in April 2016 and took about 30-45 min. The participants work in different industries (food and beverages, machinery, chemicals, services)

\section{Acknowledgements}

Not applicable.

\section{Funding}

We acknowledge support for the Article Processing Charge by the German Research Foundation and the Open Access Publication Fund of the Technische Universität IImenau.

\section{Availability of data and materials}

Data are partly not available from public sources.

\begin{abstract}
Authors' contributions
Both authors made substantial contributions to the conception and research design, data collection, analysis as well as to the interpretation of data in this paper. Both authors participated in drafting and revising the paper. Both authors gave final approval of the version being submitted to this journal.
\end{abstract}

\section{Competing interests}

The authors declare that they have no competing interests.

\section{Publisher's Note}

Springer Nature remains neutral with regard to jurisdictional claims in published maps and institutional affiliations.
Received: 12 November 2017 Accepted: 7 February 2018

Published online: 21 February 2018

\section{References}

Adhikari, A., \& Tondkar, R. H. (1992). Environmental factors influencing accounting disclosure requirements of global stock exchanges. Journal of International Financial Management \& Accounting, 4(2), 75-105.

Albert, S., \& Whetten, D. A. (1985). Organization identity. Research on Organizational Behavior, 7, 263-295.

Archer, D. (2009). In D. Archer (Ed.), What's in a word-list?: Investigating word frequency and keyword extraction. Farnham, Burlington: Ashgate Publishing.

Balmer, J. M. T. (2001). Corporate identity, corporate branding and corporate marketing-seeing through the fog. European Journal of Marketing, 35(3), 248291. https://doi.org/10.1108/03090560110694763.

Balmer, J. M. T., \& Greyser, S. A. (2003). Revealing the corporation: Perspectives on identity, image, reputation, corporate branding, and corporate-level Marketing : An anthology. London, New York: Routledge.

Balmer, J. M. T., \& Greyser, S. A. (2006). Corporate marketing: Integrating corporate identity, corporate branding, corporate communications, corporate image and corporate reputation. European Journal of Marketing, 40(7/8), 730-741. https://doi.org/10.1108/03090560610669964.

Baumann-Pauly, D., Wickert, C., Spence, L. J., \& Scherer, A. G. (2013). Organizing corporate social responsibility in small and large firms: Size matters. Journal of Business Ethics, 115(4), 693-705. https://doi.org/10.1007/s10551-013-1827-7.

Baumgarth, C., \& Binckebanck, L. (2011). Glaubwürdige CSR-Kommunikation durch eine identitätsbasierte CSR-Markenführung: Forschungsstand und konzeptionelles Modell. Uwf UmweltWirtschaftsForum, 19(3-4), 199-205. https://doi.org/10.1007/s00550-011-0212-1.

Bondy, K., Moon, J., \& Matten, D. (2012). An institution of corporate social responsibility (CSR) in multi-National Corporations (MNCs): Form and implications. Journal of Business Ethics, 111(2), 281-299.

Boulding, K. E. (1956). The image: Knowledge in life and society. Michigan: University of Michigan Press.

Branco, M. C., \& Rodrigues, L. L. (2006). Corporate social responsibility and resource-based perspectives. Journal of Business Ethics, 69(2), 111-132. https://doi.org/10.1007/s10551-006-9071-z.

Brennan, N. M., Merkl-Davies, D. M., \& Beelitz, A. (2013). Dialogism in corporate social responsibility communications: Conceptualising verbal interaction between Organisations and their audiences. Journal of Business Ethics, 115(4), 665-679. https://doi.org/10.1007/s10551-013-1825-9.

Brown, H. S., de Jong, M., \& Levy, D. L. (2009). Building institutions based on information disclosure: Lessons from GRl's sustainability reporting. Journal of Cleaner Production, 17(6), 571-580. https://doi.org/10.1016/j.jclepro.2008.12.009.

Carroll, A. B., \& Shabana, K. M. (2010). The business case for corporate social responsibility: A review of concepts, research and practice. International Journal of Management Reviews, 12(1), 85-105. https://doi.org/10.1111/j.1468-2370.2009.00275.x.

Chen, S., \& Bouvain, P. (2009). Is corporate responsibility converging? A comparison of corporate responsibility reporting in the USA, UK, Australia, and Germany. Journal of Business Ethics, 87(SUPPL.1), 299-317.

Cho, C. H., Guidry, R. P., Hageman, A. M., \& Patten, D. M. (2012). Do actions speak louder than words? An empirical investigation of corporate environmental reputation. Accounting, Organizations and Society, 37(1), 14-25.

Cho, C. H., Michelon, G., Patten, D. M., \& Roberts, R. W. (2015). CSR disclosure: The more things change...? Accounting, Auditing \& Accountability Journal, 28(1), 14-35.

Cho, C. H., \& Patten, D. M. (2007). The role of environmental disclosures as tools of legitimacy: A research note. Accounting, Organizations and Society, 32(7-8), 639-647. https://doi.org/10.1016/j.aos.2006.09.009.

Cho, S. Y., Lee, C., \& Pfeiffer, R. J. (2013). Corporate social responsibility performance and information asymmetry. Journal of Accounting and Public Policy, 32(1), 71-83. https://doi.org/10.1016/j.jaccpubpol.2012.10.005.

Clarkson, P. M., Fang, X., Li, Y., \& Richardson, G. D. (2013). The relevance of environmental disclosures: Are such disclosures incrementally informative? Journal of Accounting and Public Policy, 32(5), 410-431. https://doi.org/10. 1016/j.jaccpubpol.2013.06.008.

Clarkson, P. M., Li, Y., Richardson, G. D., \& Vasvari, F. P. (2008). Revisiting the relation between environmental performance and environmental disclosure: An empirical analysis. Accounting, Organizations and Society, 33(4-5), 303-327. https://doi.org/10.1016/j.aos.2007.05.003.

Collier, J., \& Esteban, R. (2007). Corporate social responsibility and employee commitment. Business Ethics: A European Review, 16(1), 19-33. https://doi.org/ 10.1111/j.1467-8608.2006.00466.x. 
Cornelissen, J. P. (2002). On the " organizational identity " metaphor. British Journal of Management, 13, 259-268.

Dhaliwal, D. S., Li, O. Z., Tsang, A., \& Yang, Y. G. (2011). Voluntary nonfinancial disclosure and the cost of equity capital: The initiation of corporate social responsibility reporting. The Accounting Review, 86(1), 59-100.

Dhaliwal, D. S., Li, O. Z., Tsang, A., \& Yang, Y. G. (2014). Corporate social responsibility disclosure and the cost of equity capital: The roles of stakeholder orientation and financial transparency. Journal of Accounting and Public Policy, 33(4), 328-355. https://doi.org/10.1016/j.jaccpubpol.2014.04.006.

Dhaliwal, D. S., Tsang, A., Radhakrishnan, S., \& Yang, Y. G. (2012). Nonfinancial disclosure and analyst forecast accuracy: International evidence on corporate social responsibility disclosure. The Accounting Review, 87(3), 723-759. https:// doi.org/10.2308/accr-10218.

Du, S., Bhattacharya, C. B., \& Sen, S. (2010). Maximizing business returns to corporate social responsibility (CSR): The role of CSR communication. International Journal of Management Reviews, 12(1), 8-19. https://doi.org/10. 1111/j.1468-2370.2009.00276.x.

Dye, R. A. (1990). Mandatory versus voluntary disclosures: The cases of financial and real externalities. The Accounting Review, 65(1), 1-24.

Einwiller, S., \& Will, M. (2002). Towards an integrated approach to corporate branding - An empirical study. Corporate Communications: An International Journal, 7(2), 100-109. https://doi.org/10.1108/13563280210426160.

Engert, S., Rauter, R., \& Baumgartner, R. J. (2016). Exploring the integration of corporate sustainability into strategic management: A literature review. Journal of Cleaner Production, 112, 2833-2850. https://doi.org/10.1016/j.jclepro.2015.08.031.

Ericsson, K. A. (2006). The influence of experience and deliberate practice on the development of superior expert performance. In K. A. Ericsson, N. Charness, P. J. Feltovich, \& R. R. Hoffman (Eds.), The Cambridge handbook of expertise and expert performance (pp. 685-706). Cambridge: Cambridge University Press.

Farrar, D. E., \& Glauber, R. R. (1967). Multicollinearity in regression analysis: The problem revisited. The Review of Economics and Statistics, 49(1), 92-107. https://doi.org/10.2307/1926450.

Fatma, M., Khan, I., \& Rahman, Z. (2016). The effect of CSR on consumer behavioral responses after service failure and recovery. European Business Review, 28(5), 583-599. https://doi.org/10.1108/EBR-11-2015-0134.

Fifka, M. S. (2013). Corporate responsibility reporting and its determinants in comparative perspective - a review of the empirical literature and a meta-analysis. Business Strategy and the Environment, 22(1), 1-35. https:/doi.org/10.1002/bse.729.

Fischer, T. M., \& Sawczyn, A. A. (2013). The relationship between corporate social performance and corporate financial performance and the role of innovation: Evidence from German listed firms. Journal of Management Control, 24(1), 27-52.

Fortanier, F., Kolk, A., \& Pinkse, J. (2011). Harmonization in CSR reporting. Management International Review, 51(5), 665-696.

Francis, J., Nanda, D., \& Olsson, P. (2008). Voluntary disclosure, earnings quality, and cost of capital. Journal of Accounting Research, 46(1), 53-99. https://doi. org/10.1111/j.1475-679X.2008.00267.x.

Gamerschlag, R., Möller, K., \& Verbeeten, F. (2010). Determinants of voluntary CSR disclosure: Empirical evidence from Germany. Review of Managerial Science, 5(2-3), 233-262.

Gioia, D. A., Schultz, M., \& Corley, K. G. (2000). Organizational identity, image, and adaptive instability. The Academy of Management Review, 25(1), 63-81.

Grüning, M. (2011). Artificial intelligence measurement of disclosure (AIMD). European Accounting Review, 20(3), 485-519.

Guidry, R. P., \& Patten, D. M. (2012). Voluntary disclosure theory and financial control variables: An assessment of recent environmental disclosure research. Accounting Forum, 36(2), 81-90.

Hahn, R., \& Kühnen, M. (2013). Determinants of sustainability reporting: A review of results, trends, theory, and opportunities in an expanding field of research. Journal of Cleaner Production, 59, 5-21. https://doi.org/10. 1016/j.jclepro.2013.07.005

Haniffa, R. M., \& Cooke, T. E. (2005). The impact of culture and governance on corporate social reporting. Journal of Accounting and Public Policy, 24(5), 391-430.

He, H.-W., \& Balmer, J. M. T. (2007). Identity studies: Multiple perspectives and implications for corporate-level marketing. European Journal of Marketing, 41(7), 765-785. https://doi.org/10.1108/03090560710752393.

He, H.-W., \& Balmer, J. M. T. (2013). A grounded theory of the corporate identity and corporate strategy dynamic: A corporate marketing perspective. European Journal of Marketing, 47(3), 401-430. https://doi.org/10.1108/ 03090561311297391.
Healy, P. M., \& Palepu, K. G. (2001). Information asymmetry, corporate disclosure, and the capital markets: A review of the empirical disclosure literature. Journal of Accounting and Economics, 31(1-3), 405-440. https://doi.org/10. 1016/S0165-4101(01)00018-0.

Heikkurinen, P., \& Ketola, T. (2012). Corporate responsibility and identity: From a stakeholder to an awareness approach. Business Strategy and the Environment, 21(5), 326-337. https://doi.org/10.1002/bse.744.

Heitzman, S., Wasley, C., \& Zimmerman, J. L. (2010). The joint effects of materiality thresholds and voluntary disclosure incentives on firms' disclosure decisions. Journal of Accounting and Economics, 49(1-2), 109-132. https://doi.org/10. 1016/j.jacceco.2009.10.002.

Hopwood, A. G. (2009). Accounting and the environment. Accounting, Organizations and Society, 34(3-4), 433-439. https://doi.org/10.1016/j.aos. 2009.03.002.

Hristache, D. A., Paicu, C. E., \& Ismail, N. (2013). Corporate social responsibility and organizational identity in post-crisis economy. Theoretical and Applied Economics, 20(1), 113-120

Huang, C., Yen, S., Management, D., Liu, C., \& Huang, P. (2014). The relationship among corporate social responsibility, service quality, corporate image and purchase intention. International Journal of Organizational Innovation, 6(3), 68-85.

Jackson, G., \& Apostolakou, A. (2010). Corporate social responsibility in Western Europe: An institutional mirror or substitute? Journal of Business Ethics, 94, 371-394. https://doi.org/10.1007/s10551-009-0269-8.

Laufer, W. S. (2014). Corporate social accountability and greenwashing. Journal of Business Ethics, 43(3), 253-261.

Liu, M. T., Wong, I. A., Shi, G., Chu, R., Brock, J. L., Liu, M. T., et al. (2014). The impact of corporate social responsibility ( CSR ) performance and perceived brand quality on customer-based brand preference. Journal of Services Marketing, 28(3), 181-194. https://doi.org/10.1108/JSM-09-2012-0171.

Lock, l., \& Seele, P. (2016). The credibility of CSR (corporate social responsibility) reports in Europe. Evidence from a quantitative content analysis in 11 countries. Journal of Cleaner Production, 122, 186-200. https://doi.org/10. 1016/j.jclepro.2016.02.060.

Lozano, R. (2012). Towards better embedding sustainability into companies' systems: An analysis of voluntary corporate initiatives. Journal of Cleaner Production, 25, 14-26. https://doi.org/10.1016/j.jclepro.2011.11.060.

Lozano, R. (2013). Are companies planning their organisational changes for corporate sustainability? An analysis of three case studies on resistance to change and their strategies to overcome it. Corporate Social Responsibility and Environmental Management, 20(5), 275-295. https:/doi.org/10.1002/csr.1290.

Lozano, R. (2015). A holistic perspective on corporate sustainability drivers. Corporate Social Responsibility and Environmental Management, 22(1), 32-44. https://doi.org/10.1002/csr.1325.

Lozano, R., Nummert, B., \& Ceulemans, K. (2016). Elucidating the relationship between sustainability reporting and Organisational change Management for Sustainability. Journal of Cleaner Production, 125, 168-188. https://doi.org/10. 1016/j.jclepro.2016.03.021.

Margulies, W. P. (1977). Make the most of your corporate identity. Harvard Business Review, 55(4), 66-72.

Martins, E. (2007). Beteiligungsorientierte Unternehmenskultur: Konzept und Messung (No. 7). Arbeitspapier aus dem Projekt Transfer Innovativer Unternehmensmilieus, pp. 44-73.

McShane, L., \& Cunningham, P. (2011). To thine own self be true? Employees' judgments of the authenticity of their Organization's corporate social responsibility program. Journal of Business Ethics, 108(1), 81-100. https://doi. org/10.1007/s10551-011-1064-x.

McWilliams, A., \& Siegel, D. S. (2001). Note corporate social Responsibility : A theory of the firm perspective. Academy of Management Journal, 26(1), 117-127.

McWilliams, A., Siegel, D. S., \& Wright, P. M. (2006). Guest editors' introduction corporate social Responsibility : Strategic implications. Journal of Management Studies, 43(1), 1-18.

Melewar, T. C., \& Karaosmanoglu, E. (2006). Seven dimensions of corporate identity. European Journal of Marketing, 40(7/8), 846-869. https://doi.org/10. 1108/03090560610670025.

Michaels, A., \& Grüning, M. (2016a). Glaubwürdigkeit von CSR-Konzepten - Die Einflüsse von CSR-Publizität und Corporate Identity auf CSR-Reputation. Uwf UmweltWirtschaftsForum, 24(2-3), 179-193. https://doi.org/10.1007/s00550016-0414-7.

Michaels, A., \& Grüning, M. (2016b). Interne Treiber von CSR-Publizität: Der Einfluss von Corporate Identity. Uwf UmweltWirtschaftsForum, 24(4), 315-324. https://doi.org/10.1007/s00550-016-0421-8. 
Michaels, A., \& Grüning, M. (2017). Relationship of corporate social responsibility disclosure on information asymmetry and the cost of capital. Journal of Management Control, 28(3), 251-274. https://doi.org/10.1007/s00187-017-0251-z.

Nelling, E., \& Webb, E. (2008). Corporate social responsibility and financial performance: The "virtuous circle" revisited. Review of Quantitative Finance and Accounting, 32(2), 197-209.

Newell, S. J., \& Goldsmith, R. E. (2001). The development of a scale to measure perceived corporate credibility. Journal of Business Reserach, 52(3), 235-247.

Nijhof, A. H. J., \& Jeurissen, R. J. M. (2010). The glass ceiling of corporate social responsibility: Consequences of a business case approach towards CSR. International Journal of Sociology and Social Policy, 30(11/12), 618-631.

Nikolaeva, R., \& Bicho, M. (2011). The role of institutional and reputational factors in the voluntary adoption of corporate social responsibility reporting standards. J Acad Mark Sci, 39(1), 136-157.

Once, S., \& Almagtome, A. (2014). The relationship between Hofstede's national culture values and corporate environmental disclosure: An international perspective. Research Journal of Business and Management, 1(3), 279-304

Otubanjo, O. (2013). Theorising the interconnectivity between corporate social responsibility ( CSR ) and corporate identity. Journal of Management and Sustainability, 3(1), 74-94. https://doi.org/10.5539/jms.v3n1p74.

Pérez, A., \& Rodríguez del Bosque, I. (2011). The role of CSR in the corporate identity of banking service providers. Journal of Business Ethics, 108(2), 145166. https://doi.org/10.1007/s10551-011-1067-7.

Plumlee, M. A., Brown, D., Hayes, R. M., \& Marshall, R. S. (2015). Voluntary environmental disclosure quality and firm value: Further evidence. Journal of Accounting and Public Policy, 34(4), 336-361. https://doi.org/10.1016/j. jaccpubpol.2015.04.004

Porter, M. E., \& Kramer, M. R. (2006). Stategy \& Society - the link between competitive advantage and corporate social responsibility. Harvard Business Review, 84(12), 78-92

Reverte, C. (2012). The impact of better corporate social responsibility disclosure on the cost of equity capital. Corporate Social Responsibility and Environmental Management, 19(5), 253-272.

Rouf, A. (2011). Corporate characteristics, governance attributes and the extent of voluntary disclosure in Bangladesh. African Journal of Business Management, 5(19), 7836-7845. https://doi.org/10.5897/AJBM10.1180.

Russo, M. V., \& Fouts, P. A. (1997). A resource-based perspective on corporate environmental performance and profitability. Academy of Management Journal, 40(3), 534-559. https://doi.org/10.2307/257052.

Sackmann, S. (2006). Messen-Werten-Optimieren. Erfolg durch Unternehmenskultur. Gütersloh: Bertelsmann Stiftung.

Shnayder, L., van Rijnsoever, F. J., \& Hekkert, M. P. (2016). Motivations for corporate social responsibility in the packaged food industry: An institutional and stakeholder management perspective. Journal of Cleaner Production, 122, 212-227. https://doi.org/10.1016/j.jclepro.2016.02.030.

Simon, H. (2012). Hidden Champions - Aufbruch nach Globalia: Die Erfolgsstrategien unbekannter Weltmarktführer. Frankfurt am Main, New York: Campus Verlag.

Spiegel, F., \& Block, J. (2013). Regionale Bedeutung von Familienunternehmen. Zeitschrift Für KMU Und Entrepreneurship, 2(1-2), 7-34. https://doi.org/10.3790/zfke.61.1-2.7.

Strand, R. (2014). Strategic leadership of corporate sustainability. Journal of Business Ethics, 123(4), 687-706. https://doi.org/10.1007/s10551-013-2017-3.

Sustainalytics. (2012). Die Nachhaltigkeitsleistungen deutscher Großunternehmen. Retrieved 15 March 2015, from http://www.sustainalytics.com/sites/default/ files/sustainalytics_dax_30_studie_2011_0.pdf

Unterreitmeier, A. (2004). Unternehmenskultur bei Mergers \& Acquisitions: Ansätze zu Konzeptualisierung und Operationalisierung. Berlin, Heidelberg: Springer Verlag.

Van der Laan Smith, J., Adhikari, A., \& Tondkar, R. H. (2005). Exploring differences in social disclosures internationally: A stakeholder perspective. Journal of Accounting and Public Policy, 24(2), 123-151. https://doi.org/10.1016/j. jaccpubpol.2004.12.007.

Van Riel, C. B. M., \& Fombrun, C. J. (2007). Essentials of corporate communication: Implementing practices for effective reputation management. London, New York: Taylor \& Francis Retrieved from http://books.google.de/books/about/ Essentials_of_Corporate_Communication.html?id=4Jltn6S4NSkC\&pgis=1.

Venturelli, A., Caputo, F., Leopizzi, R., \& Mastroleo, G. (2017). How can CSR identity be evaluated? A pilot study using a fuzzy expert system. Journal of Cleaner Production, 141, 1000-1010. https://doi.org/10.1016/j.jclepro.2016.09.172.

Verrecchia, R. E. (1983). Discretionary disclosure. Journal of Accounting and Economics, 5, 179-194. https://doi.org/10.1016/0165-4101(90)90021-U.
Wickert, C., Scherer, A. G., \& Spence, L. J. (2016). Walking and talking corporate social Responsibility : Implications of firm size and organizational cost. Journal of Management Studies, 1-28. https://doi.org/10.1111/joms.12209.

Willis, G. (2006). Cognitive interviewing as a tool for improving the informed consent process. Journal of Empirical Research on Human Research Ethics, 1(1), 9-24. https://doi.org/10.1525/jer.2006.1.1.9.

Young, S., \& Marais, M. (2012). A multi-level perspective of CSR reporting: The implications of National Institutions and industry risk characteristics. Corporate Governance: An International Review, 20(5), 432-450. https://doi.org/ 10.1111/j.1467-8683.2012.00926.x.

\section{Submit your manuscript to a SpringerOpen ${ }^{\circ}$ journal and benefit from:}

- Convenient online submission

- Rigorous peer review

- Open access: articles freely available online

- High visibility within the field

- Retaining the copyright to your article

Submit your next manuscript at springeropen.com 